\title{
A Arqueologia de Dois Santuários Cretenses de Zeus Dicteu: O caso de Palaikastro e de Praisos da Idade do Ferro ATÉ A ÉPOCA HELENÍSTICA
}

\author{
Lilian de Angelo Laky ${ }^{1}$
}

\section{RESUMO}

A partir dos casos dos santuários de Zeus Dicteu em Palaikastro e Praisos, no leste de Creta, apresentamos, neste artigo, a metodologia da arqueologia dos santuários gregos. A partir de um exame minucioso das fontes arqueológicas (principalmente oferendas votivas) e das fontes literárias, em associação ao espaço dos santuários na paisagem e no território das cidades gregas, discutiremos o papel dos santuários de Zeus Dicteu no contexto da formação da pólis nesse lado de Creta e na articulação dos territórios e da identidade das comunidades políticas dessa região até a época helenística. Em última análise, objetivamos mostrar como fontes diferentes se articulam e podem revelar o papel social dos santuários gregos.

\section{PALAVRAS-CHAVE}

Zeus Dicteu; Creta; santuário; Palaikastro; Praisos.

\footnotetext{
${ }^{1}$ Mestre e doutora em Arqueologia pelo Museu de Arqueologia e Etnologia da USP (MAE-USP), pósdoutoranda em História Social no Departamento de História (FAPESP, FFLCH-USP). Pesquisadora do Laboratório de Estudos sobre o Império Romano e Mediterrâneo Antigo (LEIR-MA/USP). Essa pesquisa, cujos resultados aparecem neste artigo, foi financiada pela FAPESP (Processo no. 2011/12709-9) e realizada no Laboratório de Estudos sobre a Cidade Antiga (LABECA-MAE/USP). E-mail de contato: lilian.laky@usp.br
} 
Mare Nostrum, ano 2020, v. 11, n. 2.

1. Introdução

A ilha de Creta, como o Peloponeso, concentra a maior quantidade dos santuários mais antigos dedicados a Zeus no mundo grego, sendo a única região onde está a maior parte daqueles que remontam à Idade do Bronze (Laky, 2016, p. 77). Entre a Idade do Bronze e a época clássica, as fontes arqueológicas e/ou literárias indicam que Zeus possuiu seis santuários, sendo dois datados a partir da Idade do Bronze (Mt. Ida e Mt. Dicta) e quatro datados a partir da Idade do Ferro (Agia Triada, Amnisos, Palaikastro e Praisos). Os santuários de Zeus encontram-se estabelecidos, predominantemente, no lado central e extremo oriental de Creta, não havendo áreas sagradas, dedicadas ao seu culto, na porção extremo ocidental da ilha. Creta é conhecida como o local do nascimento de Zeus. A tradição literária atribui três locais ao episódio mítico: as grutas no Monte Ida e no Monte Dicta e o Monte Aigaion. Há uma explicação coerente sobre a variedade de versões desse mito e sua origem em períodos mais antigos. Segundo Thorne, "o fato de que diferentes tradições localizem o local de nascimento de Zeus no Ida, no Dicta e no Aigaion, assim como em vários lugares na Arcádia, no Peloponeso, pode indicar a difusão de um mito relacionado na Idade do Bronze e uma subsequente fragmentação em variantes locais e regionais durante a Idade do Ferro" (Prent e Thorne, 2000, p. 141, pp. 153-154; Prent, 2005, p. 602).

De todo modo, dentre esses três lugares, as grutas localizadas no Monte Ida (no centro-oeste) e no Monte Dicta (no centro-leste) foram conhecidas como os locais mais famosos e nelas foram estabelecidos santuários datados a partir da Idade do Bronze até a época romana, atribuídos ao culto de Zeus com base em testemunhos posteriores epigráficos e literários (Ida) ${ }^{2}$ e literários (Dicta). Sobre a gruta de Dicta, atribui-se a sua localização à atualmente denominada de gruta de Psychro, localizada no Monte Dicta (ainda atual nome da montanha). Diferente da gruta de Ida, para a qual não há controvérsias acerca da atribuição do santuário a Zeus, sobre a gruta de Psychro, em razão da ausência de evidências epigráficas no local, até hoje permanecem dúvidas se de fato ali funcionou o santuário da divindade relacionado à versão do mito, conservado em Apolodoro (Apollod., 1.1.6), que localiza o nascimento de Zeus na gruta de Dicta (Laky, 2016, p. 88).

\footnotetext{
${ }^{2}$ A identificação do culto de Zeus no santuário na gruta de Ida é confirmada por uma inscrição romana (I.Cret. I, XII.I) e por um grande trecho conservado em Diodoro (Diod., V.70.1-2/2-6) (Prent, 2005, p. 591).
} 


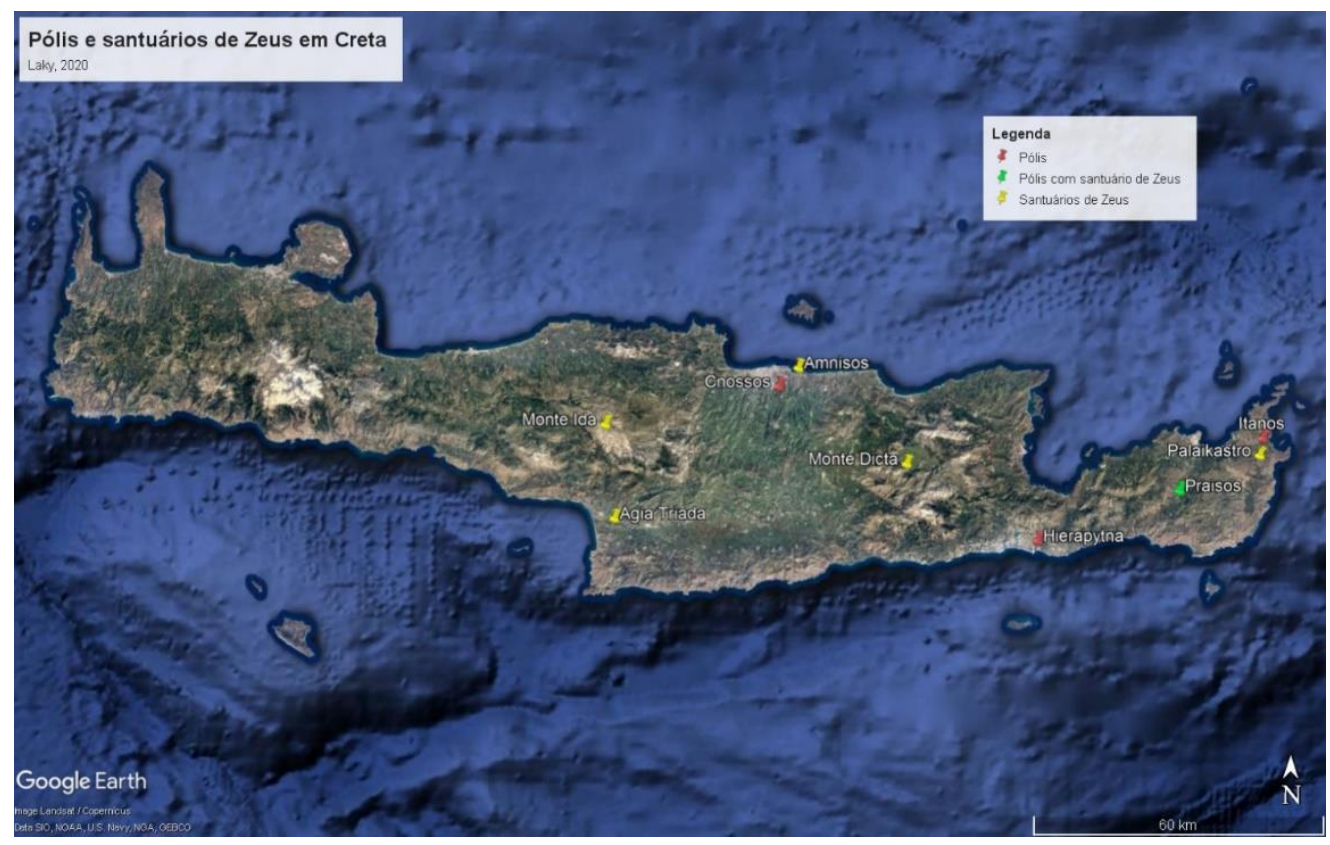

Durante o período minoico e o início da Idade do Ferro, "o nascimento e juventude de Zeus foram celebrados em vários tipos de santuários por toda Creta (como também no período clássico e períodos posteriores)" (Watrous, 1996, p. 19). O santuário de Dicta ou Psychro foi, portanto, provavelmente um dos vários santuários dedicados ao jovem Zeus cretense na ilha (Watrous, 1996, p. 19). É preciso explicar que na ilha de Creta, Zeus foi caracterizado pelo sincretismo de uma divindade jovem minoica, ligada ao reflorescimento da vegetação, com o deus celeste micênico da Grécia balcânica. Ao longo de sua formação histórica esse Zeus cretense foi cultuado em santuários com diversos epítetos, dentre eles Dicteu (Watrous, 1996, p. 19).

Os diferentes epítetos refletem diferentes tradições sobre versões do mito de Zeus em Creta, e Dicteu parece ser o mais antigo dentre eles, como indica uma referência em um tablete de Cnossos ${ }^{3}$. De acordo com O. Zolotnikova, o culto de Zeus Dicteu, localizado inicialmente no lado central de Creta, tal como defende Watrous, teria se difundido ao leste da ilha na Idade do Ferro, explicando a introdução de seu culto em Palaikastro e Praisos nessa época, durante o movimento da população minoica-micênica à essa área, ocorrido no final da Idade do Bronze (Zolotnikova, 2013, p. 115). Essa é também a opinião de M. Prent (Prent, 2005, p. 594).

\footnotetext{
${ }^{3}$ Trata-se de uma oferenda de óleo a Zeus Dicteu, registrado no tablete em Linear B (Fp1) de Cnossos, que levou Watrous a propor a localização da caverna em uma área na porção central de Creta (Watrous, 1996, pp. 18-19).
} 
Mare Nostrum, ano 2020, v. 11, n. 2.

Neste artigo, interessa-nos o caso do culto de Zeus Dicteu, difundido no lado leste de Creta, onde ganhou expressão nas áreas de Palaikastro e de Praisos. A partir de um exame minucioso das fontes arqueológicas (principalmente oferendas votivas) e das fontes literárias, em associação ao espaço dos santuários na paisagem e território das cidades gregas no extremo leste de Creta, nossa intenção é discutir o papel dos santuários de Zeus Dicteu no contexto da formação da pólis nesse lado de Creta e na articulação dos territórios e da identidade das comunidades políticas dessa região. Como veremos mais adiante, dentre os cultos de Zeus em Creta, aquele sob o epíteto Dicteu é o que possui as características autóctones cretenses mais importantes.

\section{O santuário de Zeus Dicteu em Palaikastro}

O santuário de Zeus em Palaikastro foi estabelecido na Idade do Ferro sobre as ruínas de um assentamento da Idade do Bronze, datado a partir do minoico antigo (31002000 a.C.) e abandonado no final do período minoico tardio IIIC (1200-1100 a.C.; Figura 1; Prent, 2005, p. 532).

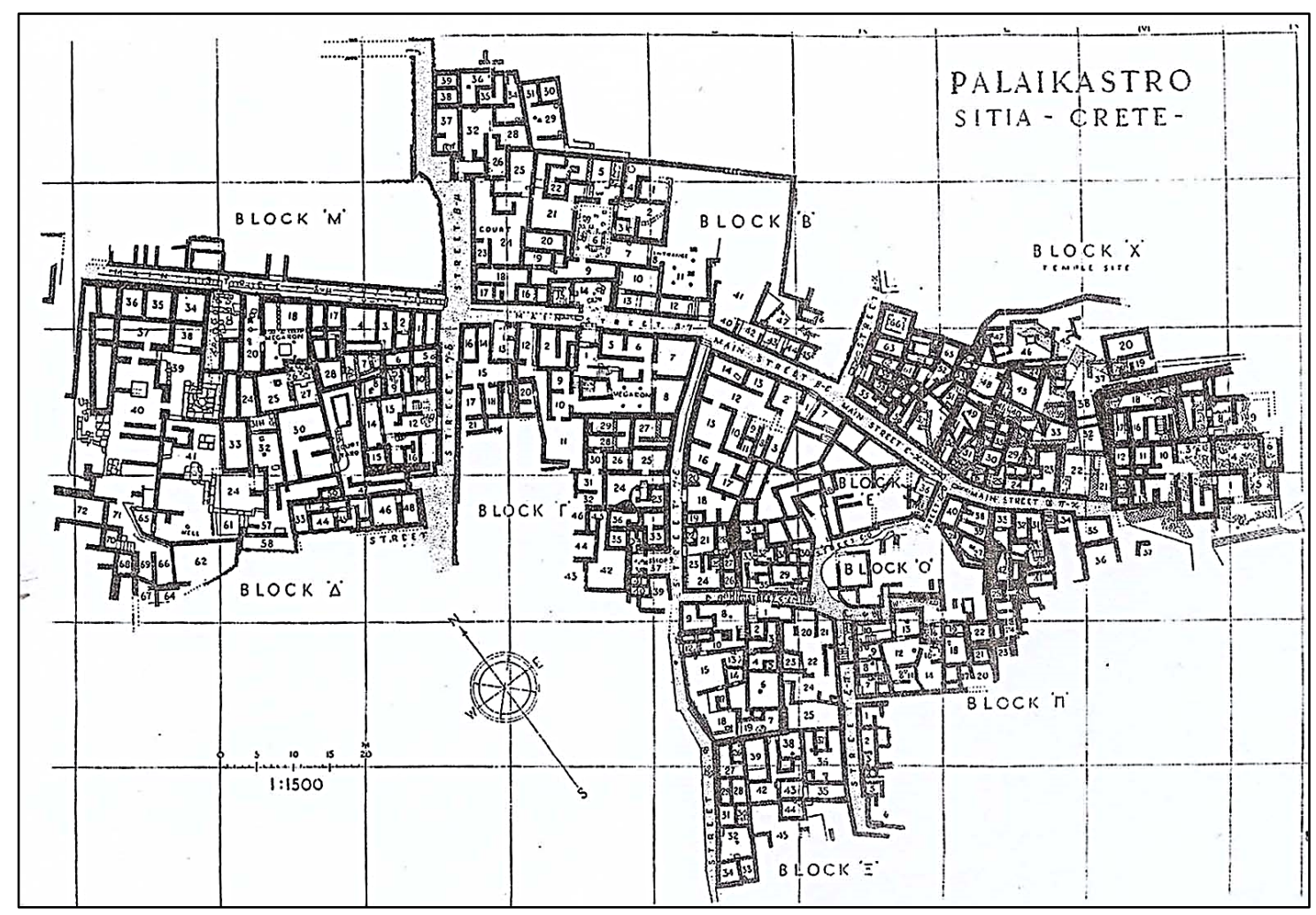

Figura 1. Planimetria geral de Palaikastro.

Fonte: Thorne \& Prent, 2000, Figura 1. 
Situado no extremo leste de Creta, no vale fértil costeiro de Roussolakkos, Palaikastro foi o maior assentamento da Idade do Bronze nessa região da ilha até o final do período minoico tardio IIIB (1320-1200 a.C.), embora nunca tenha se desenvolvido em um centro palaciano, como indicam as evidências até o momento (Prent, 2005, p. 533). O santuário de Zeus em Palaikastro está entre aqueles da divindade que foram fundados em antigos assentamentos cretenses da Idade do Bronze, como é o caso, também, do santuário de Zeus Thenatas em Amnisos, no centro-norte de Creta.

O santuário de Zeus Dicteu foi localizado na área das quadras Chi e Pi, situadas na parte leste da cidade minoica (Figuras 1 e 2; Prent, 2005, p. 350). A área sagrada foi escavada, pela primeira vez, na campanha realizada, em Palaikastro entre 1902 e 1906, pela Escola Britânica de Atenas com direção de Robert Carr Bosanquet e Richard MacGillivray Dawkins (MacGillivray \& Sackett, 2010, p. 572). Na campanha de 1904 foram encontrados os fragmentos do hino a Zeus Dicteu em fossos próximos ao bloco Chi (Crowther \& MacGillivray, 2003, s/p). Em 1905, foram recuperadas partes das simae 4 do templo arcaico. Outras partes ainda foram adquiridas pelo antigo Museu de Heráclion na década de 1880, após terem sido vistas em um estábulo na área de Palaikastro (Driessen-Gaignerot, 2011, pp. 425-426). Durante as campanhas de 1987, 1988 e 1990, foram recuperados no edifício 5 os cem fragmentos da estatueta de marfim, argila e ouro denominada de Kouros de Palaikastro, atribuído ao culto de Zeus Dicteu no local e datado do período minoico tardio (1480-1425 a.C.; Sackett, 2002, s/p).

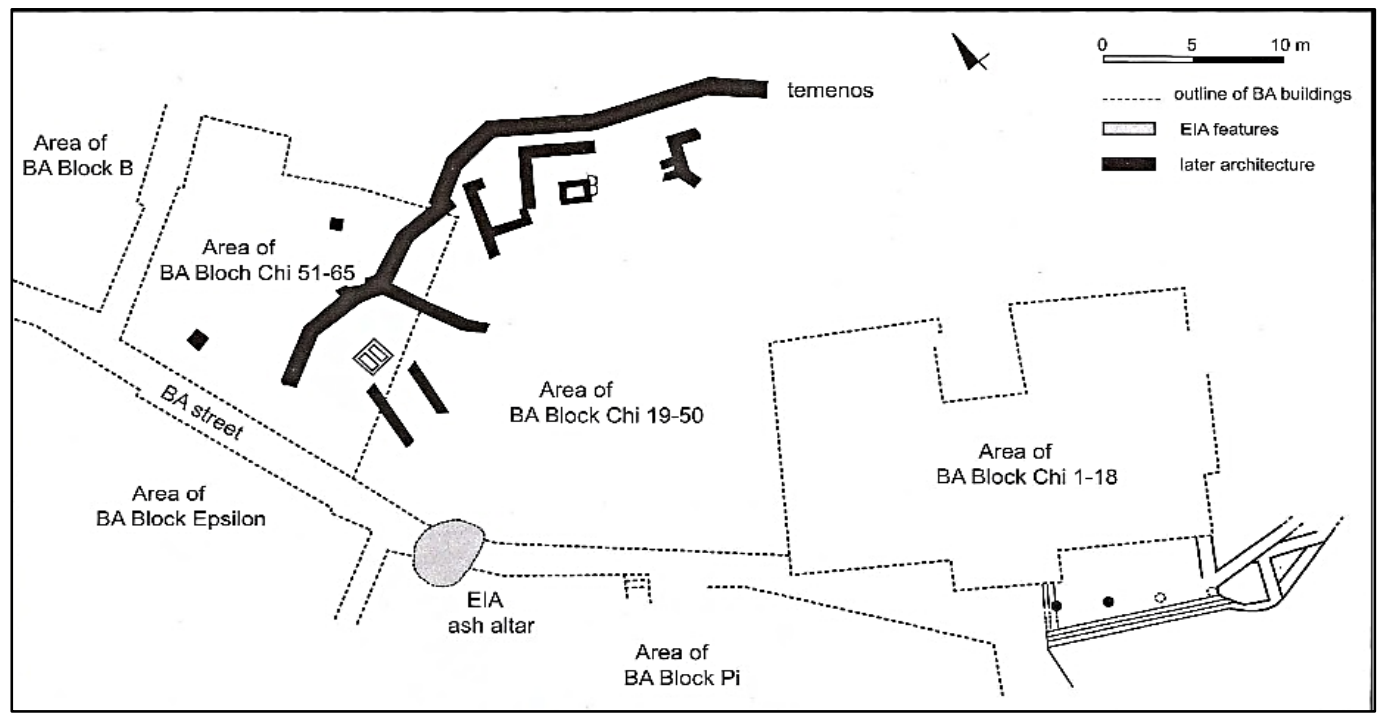

Figura 2. Planimetria do santuário de Zeus Dicteu em Palaikastro

Fonte: Prent, 2005, Figura 73.

\footnotetext{
${ }^{4}$ Em arquitetura grega, a sima funcionava como a calha nos beirais do telhado de um templo, por exemplo, e podiam ser decoradas em pedra ou em terracota dependendo do período.
} 
Mare Nostrum, ano 2020, v. 11, n. 2.

\subsection{Os achados arqueológicos}

De acordo com M. Prent, a atividade cultual na área dos blocos Chi e Pi pode ser atestada a partir do período proto-geométrico, embora as evidências sejam mais contundentes em relação aos períodos geométrico e Orientalizante (Prent, 2005, p. 350). Nenhuma estrutura arquitetônica de culto, datada da Idade do Ferro, foi encontrada, levando-se a se considerar que o culto foi realizado a céu aberto desde quando foi estabelecido em meio às ruínas da cidade minoica em Roussolakkos até a construção do templo em época arcaica (Thorne \& Prent, 2002, s/p). Até a época arcaica, o altar de cinzas deve ter sido a parte central do culto, como indica uma concentração desse material, de 0,25 $\mathrm{m}$ de espessura e $3 \mathrm{~m}$ de comprimento, encontrada ao longo das quadras Chi 25-26 e Pi 38-40 dentro da área do témeno ${ }^{5}$ arcaico (Prent, 2005, p. 351). Ali foram recuperados vários objetos, como vasilhas de bronze, selos e esculturas miniaturísticas (Prent, 2005, p. 351, 538; Watrous, 1996, p. 104).

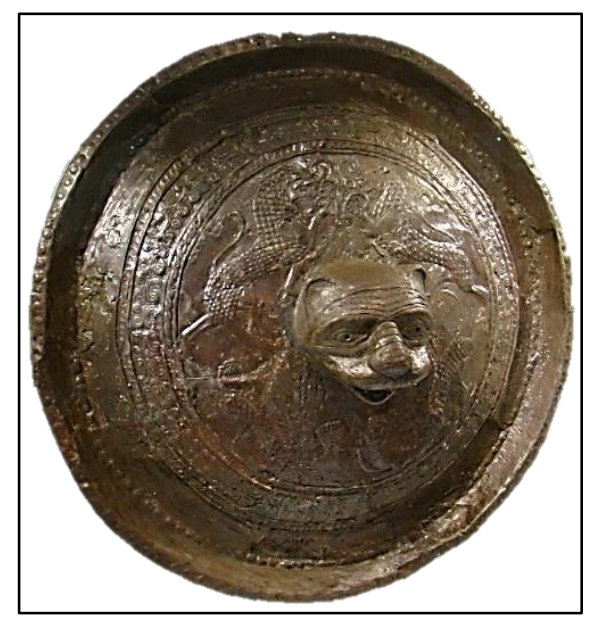

Figura 3. Escudo de bronze com prótomo de leão, período geométrico.

Museu Arqueológico Nacional de Heráclion

Foto: arquivo pessoal, 2014.

A maior parte dos objetos votivos da Idade do Ferro foi encontrada dentro do muro de témeno, mas os achados não foram restritos apenas a essa área (Prent, 2005, p. 350). Alguns objetos foram recuperados no pátio do bloco Beta e no bloco Delta (Prent, 2005, pp. 350-351). Durante o período mais antigo de culto em Roussolakkos, Zeus Dicteu

\footnotetext{
${ }^{5} \mathrm{Na}$ Grécia antiga, o témeno era o terreno sagrado, muitas vezes delimitado por muros ou por fileiras de pedras, consagrado a uma divindade, no interior do qual poderia ser erigido um altar e um templo (Glossário do LABECA, s.v. "témeno", consultado em 24/10/2020 às 11h48min.).
} 
recebeu oferendas votivas de bronze - trípodes, figurinhas de touro, escudos elaboradamente decorados (Figura 3), tipos de armadura (couraças, elmos, miniatura de escudos) - e de argila - taças e tigelas, lamparinas e suportes de tochas (MacGillivray \& Sackett, 2010, p. 575).

O achado mais antigo do santuário é a haste de um trípode de bronze, datado, possivelmente, do período proto-geométrico. Dentre os inúmeros objetos votivos encontrados, pode-se citar, do século VIII a.C., fragmentos de uma perna e a alça de trípodes de bronze, escudos de bronze decorados com figuras de animais (um deles com uma figura feminina e prótomos de leões), do início da época arcaica (século VII a.C.), um elmo em tamanho natural e um em miniatura, uma figurinha de leão em metal e figurinhas de touro (Prent, 2005, pp. 351-352). É importante ressaltar que nenhum objeto votivo de terracota (como figurinhas ou placas) foi encontrado no santuário, mas apenas vasos cerâmicos - na maior parte taças, pyxides e pithoi (Prent, 2005, p. 352).

De acordo com os especialistas desse sítio, o santuário foi monumentalizado, pela primeira vez, durante a época arcaica. Uma data no século VI a.C. para a primeira fase da construção de um templo, e para o muro do témeno (de $36 \mathrm{~m}$ de comprimento), foi proposta por M. Prent, com base em sua datação dos relevos das simae de terracota (550480 a.C.), as únicas evidências da existência de tal edifício (Driessen-Gaignerot, 2011, p. 428; Prent, 2005, pp. 350-351). Trata-se de seis blocos de terracota, cada qual medindo 0,35m x 0,65m, que formam um único friso de 3,90m de comprimento, e que retratam cenas de procissão de caçadores, conforme a interpretação mais recente (DriessenGaignerot, 2011, p. 430).

A cena retrata um carro de corrida, puxado por dois cavalos, dirigida por um auriga, sendo seguidos por dois guerreiros armados com escudos, lanças e elmos - a caça é interpretada a partir do desenho do cão embaixo dos cavalos do carro (Figura 4; DriessenGaignerot, 2011, pp. 430-431).

Segundo o estudo iconográfico e estilístico comparativo de F. Driessen-Gaignerot, as simae devem ser datadas no final do século VII a.C., em concordância com o que havia afirmado Bosanquet anteriormente (Driessen-Gaignerot, 2011, p. 430). Para tal proposição, a estudiosa se baseia nas evidências arquitetônicas dos templos cretenses datados dessa época, caracterizados pelo tipo de decoração do friso, tal como no caso do templo A de Prinias, e em exemplos de vasos decorados em relevo e de relevos de frisos, provenientes da área do Egeu (Driessen-Gaignerot, 2011, p. 428, p. 433). O fragmento de um friso em terracota, proveniente de Melos, datado do século VII a.C., retrata uma figura 
Mare Nostrum, ano 2020, v. 11, n. 2.

idêntica de um guerreiro visto nas simae de Palaikastro (Driessen-Gaignerot, 2011, p. 432).

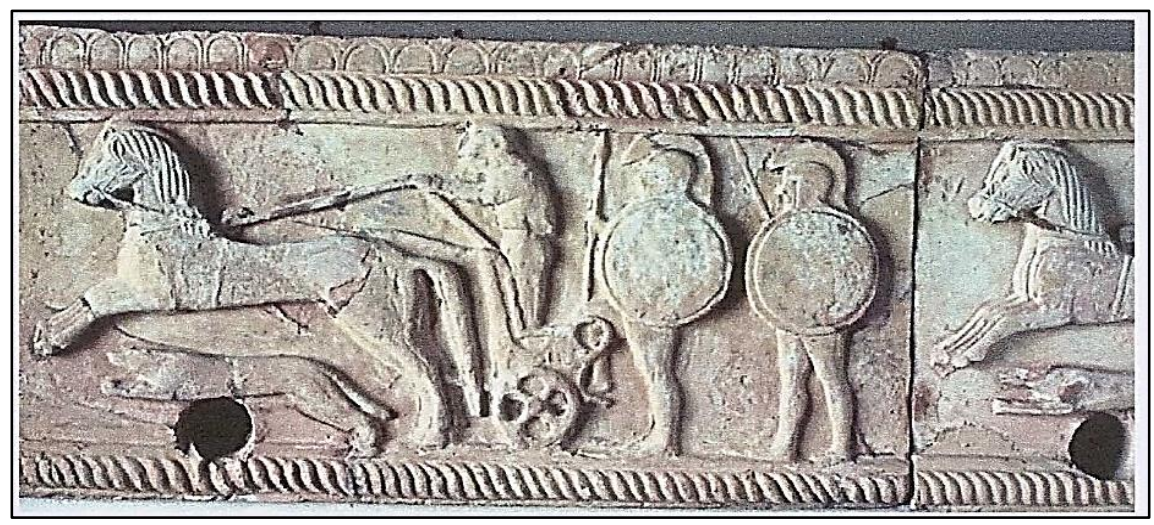

Figura 4. Friso (sima) do templo de Zeus Dicteu em Palaikastro Fonte: Drissen-Gaignerot, 2011, p. 431, Figura 4.

Uma ânfora cicládica decorada em relevo, do final do primeiro quartel do século VII a.C., proveniente de Tenos, registra cenas de batalhas entre homens e animais, uma corrida de carros ou uma procissão e uma série de hoplitas muito semelhantes àqueles do relevo de Palaikastro (Driessen-Gaignerot, 2011, p. 433). Além disso, essa mesma ânfora retrata a cena de uma divindade nascendo a partir de uma figura feminina (Métis ou Rhea), interpretada como sendo Zeus (Driessen-Gaignerot, 2011, p. 434). O paralelo iconográfico entre a cena nas simae e na ânfora de Tenos levou Driessen-Gaignerot a propor que o tema do nascimento também adornou o friso do templo arcaico de Palaikastro - em vista do hino encontrado, que evoca o renascimento perpétuo de um jovem deus, o tema nascimento de Zeus não estaria fora de contexto (Driessen-Gaignerot, 2011, p. 434).

O templo de Zeus Dicteu foi reconstruído várias vezes em períodos posteriores, como testemunham uma sequência de telhas e elementos escultóricos - uma série de antefixas de cabeças de Górgonas, datadas entre os séculos VI-V a.C. (Figura 5), e um friso de flores de lótus e palmetas encontrados no local (Prent, 2005, p. 538; Thorne e Prent, 2000 apud MacGillivray e Sackett, 2010, p. 575). 


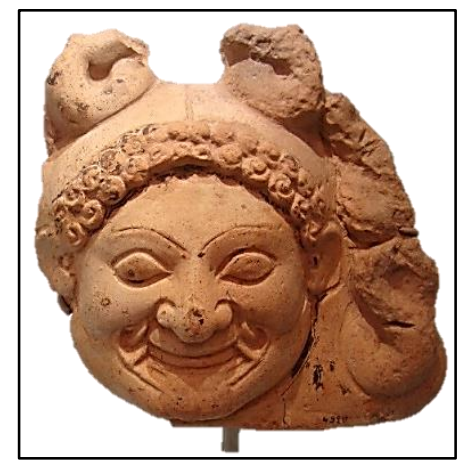

Figura 5. Sima de terracota de Górgona, segundo templo de Zeus Dicteu, Palaikastro, VI-V a.C.

Museu Arqueológico Nacional de Herácliom.

Fonte: arquivo pessoal, 2014.

O famoso hino atribuído a Zeus Dicteu, mencionado na interpretação final de F. Driessen-Gaignerot sobre as simae do templo, foi encontrado em inúmeros fragmentos em uma fossa próxima à quadra Chi (MacGillivray \& Sackett, 2010, p. 574). Trata-se de uma inscrição datada do século III d.C., cujo texto, segundo a opinião mais aceita atualmente, teria sido composto entre os séculos VI-III a.C. (Figura 6; MacGillivray \& Sackett, 2010, p. 574; Prent, 2005, p. 352). O hino faz referência ao "jovem kouros", interpretado como Zeus Dicteu, convocado a retornar à Dikte, onde estava seu altar sagrado (MacGillivray \& Sackett, 2010, p. 574). Na sequência, analisaremos a relação desse hino com o culto e a função do santuário.

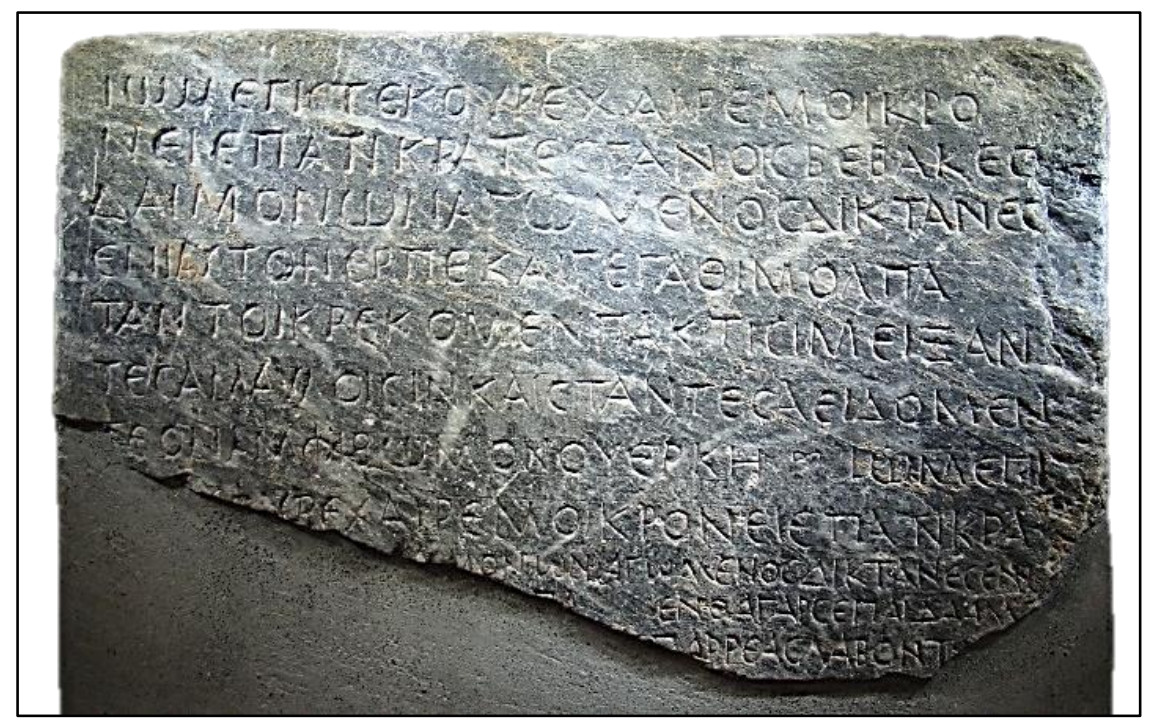

Figura 6. Primeira parte da inscrição do hino a Zeus, Séc. III d.C. Museu Arqueológico Nacional de Heráclion

Fonte: arquivo pessoal, 2014. 
Mare Nostrum, ano 2020, v. 11, n. 2.

O uso do santuário no período helenístico e romano é atestado pelos remanescentes arquitetônicos do templo de Zeus Dicteu, reconstruído também no século II a.C., e pela inscrição do hino, datado do século III d.C.

\subsection{O tipo de culto e a função do santuário}

Tal como no caso dos santuários de Ida e Amnisos, a atribuição do culto no santuário de Palaikastro a Zeus com o epíteto Dicteu tem sido aceita, pelos especialistas, com base em documentação epigráfica e literária muito posterior ao início da atividade cultual no local. No caso de Palaikastro, os especialistas têm associado a descrição da divindade, no texto do hino, às informações literárias de Diodoro e Estrabão.

Os escavadores de Palaikastro partem, em primeiro lugar, do fato de que o hino faz referência à característica do Zeus cretense, cujo culto tem raízes na jovem divindade masculina minoica, que renasce anualmente, cultuado no leste de Creta com o epíteto Dicteu $^{6}$. Em segundo lugar, a alusão a Zeus é evidenciada no hino pela referência ao deus como filho de Cronos e pelo seu chamado a retornar à Dicta. Essa seria a primeira grande prova de que o santuário de Zeus e toda a área da antiga cidade minoica de Palaikastro foi considerada como Dicta na antiguidade. Nesse sentido, o trecho de Diodoro (Diod.,5.70.6) que menciona o retorno de Zeus ao local de seu nascimento para fundar a cidade de Dicta, é tomado como mais uma evidência a esse respeito (MacGillivray \& Sackett, 2010, p. 574). Já os trechos de Estrabão (Geographia 10.4.6; 10.4.12) também são considerados como evidência da existência do culto de Zeus no santuário de Palaikastro, pois mencionam a existência de um santuário da divindade em associação à pólis de Praisos que, como veremos mais adiante, provavelmente controlou o santuário em época helenística (Prent, 2005, pp. 534-535).

Além das evidências literárias e epigráficas, datadas a partir de época helenística, que permitem associar a área de Palaikastro ao culto de Zeus Dicteu, dois achados específicos da Idade do Bronze, associados ao sítio ou à sua área, também têm sido considerados provas de uma antiga associação de Palaikastro com o culto de Zeus de Dicta. O primeiro achado se refere à inscrição JA-DI-KI-TE-TE em linear A, inscrita em mesas de libação, encontradas no santuário da Idade do Bronze localizado no topo do Mt.

\footnotetext{
${ }^{6}$ Segundo Willets, esse Zeus "nascido em Creta" foi especialmente associado à Dicta e ao epíteto Dicteu no lado leste de Creta (Willets, 1962, p. 207).
} 
Petsofas (215m), ao sul do santuário de Zeus Dicteu e do assentamento minoico de Palaikastro (Figura 7; apud Prent, 2005, p. 353).

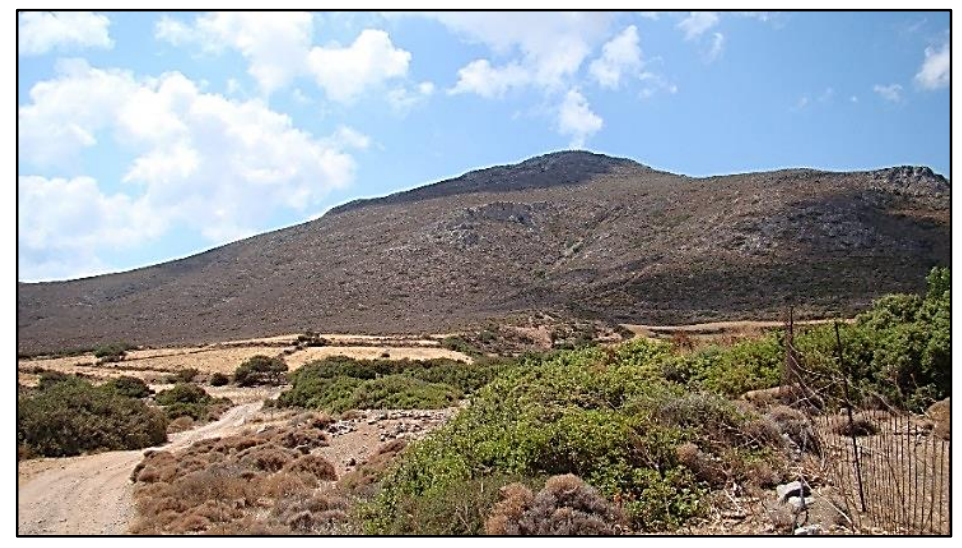

Figura 7. Mt. Petsofas visto de oeste, da área arqueológica da cidade minoica de Palaikatro Fonte: arquivo pessoal, 2014.

Essa inscrição, em associação à informação de Diodoro, levou Crowther, um dos especialistas do sítio, a identificar Dicta com esse monte e o santuário lá localizado (apud Prent, 2005, p. 353). Já o segundo achado se refere à famosa estatueta de ouro, marfim e argila denominada de Kouros de Palaikastro encontrada em centenas de fragmentos espalhados pelo edifício 5, situado a certa distância da área do santuário (Figura 8). Os especialistas têm interpretado o objeto não como um votivo, mas como uma estatueta de culto $^{7}$ (MacGillivray \& Sackett, 2000, p. 166).

Os dois tipos de evidência, em associação à referência ao grande kouros no hino de Palaikastro, têm levado os pesquisadores a "relacionar o culto existente na Idade do Bronze na área àquele celebrado no santuário na Idade do Ferro" (Prent, 2005, p. 544). Nesse sentido, "enquanto não há provas diretas da continuidade do culto em Palaikastro - há um intervalo de 300 anos entre o abandono final do edifício 5 e a dedicação do primeiro trípode de bronze no período proto-geométrico - os achados descritos sugerem uma preservação de uma associação (geral) da área de Palaikastro com o culto do deus de Dicta" (Prent, 2005, p. 544).

\footnotetext{
${ }^{7}$ Sobre essa discussão ver, MacGillivray e Sackett, 2000, p.166.
} 


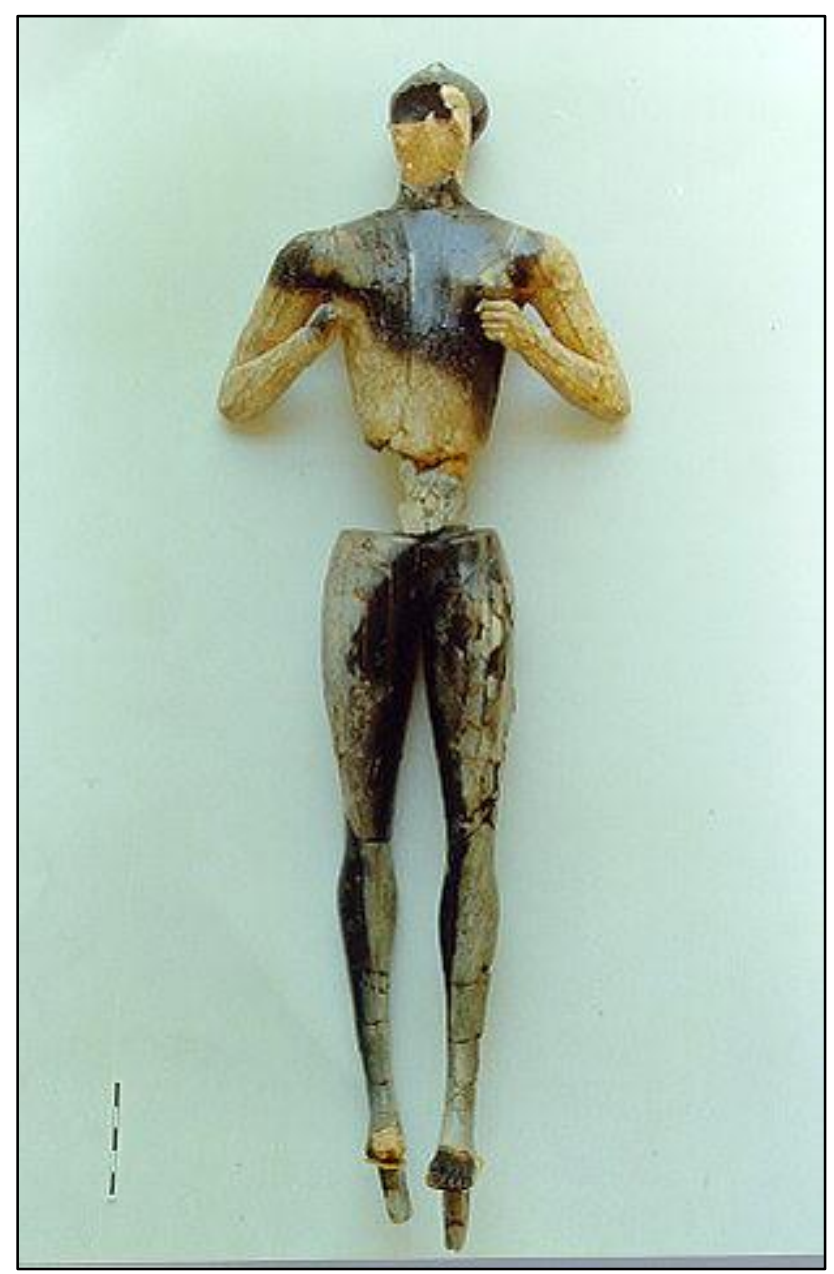

Figura 8. Kouros de Palaikastro.

Fonte: Flickr.com: The Wax Tablet, 2012.

Com relação à função do santuário, é comumente aceito entre os especialistas do sítio que o santuário de Zeus Dicteu em Palaikastro, entre a Idade do Ferro e a Época Arcaica, funcionou como um local de culto extra-urbano sub-regional - um local neutro de encontro aos membros das elites de diferentes comunidades do extremo leste de Creta (Prent, 2005, p. 537; p. 550). Os objetos votivos - a preponderância de trípodes, miniaturas ou não de escudos e outros tipos de armas e a ausência de oferendas em terracota - sugerem que o santuário foi o espaço para o desenvolvimento "de rituais relacionados às elites militares de comunidades vizinhas" (Chaniotis, 2009, p. 64). A grande presença de armas, sobretudo de escudos, é tomada, por Chaniotis, como evidência de um tipo de "ritual de efebos de várias comunidades aliadas" "representantes de uma classe mais velha" (Chaniotis, 2009, p. 64). Conforme explica esse autor, "o encontro de cidadãos jovens, os futuros guerreiros, de mais de uma cidade em um lugar sagrado, permitiu-lhes experimentar mais intensamente sua própria 
identidade, sentir mais fortemente a hostilidade e a competição com outras comunidades, e, às vezes, estabelecer alianças regionais, supra-locais” (Chaniotis, 2009, p. 65). Nessa perspectiva, o hino aos Kouretes também é tomado como evidência, para os períodos mais antigos, da realização desse ritual. De acordo com Chaniotis, é possível que "o hino tenha sido cantado pelos homens jovens durante um festival" em época arcaica ou ainda em um período anterior (Chaniotis, 2009, p. 64). Para N. Kreutz, os votivos de armas, em associação ao texto do hino dos Kouretes, permitem supor que eram realizadas, pelos efebos, danças rituais com os escudos de bronze, imitando o papel dos Kouretes na dança de guerra por meio da qual haviam protegido o pequeno Zeus (Kreutz, 2007, pp. 133134).

Sobre o estabelecimento do santuário de Zeus Dicteu sobre as ruínas da cidade minoica de Palaikastro, há algumas divergências entre os especialistas. P. Pearlman prefere relacionar a fundação do santuário ao processo de formação da pólis, apesar do desconhecimento sobre qual comunidade teria controlado a área sagrada desde a sua fundação (Pearlman, 1995, p. 164). A seu ver, "definição e proteção territoriais podem ter contribuído para a decisão de estabelecer o santuário em Palaikastro, embora também não seja possível determinar a que fronteiras a área sagrada ajudou a definir e a proteger" (Pearlman, 1995, p. 165). Com base nas similaridades entre os votivos encontrados em Palaikastro e no santuário da acrópole de Praisos (atribuído também ao culto de Zeus Dicteu), situada a alguns poucos quilômetros a sudoeste, e no testemunho de Estrabão, Pearlman defende que Praisos, desde o início, pode ter sido a cidade que controlou o santuário de Zeus Dicteu em Palaikastro (Pearlman, 1995, p. 165). Essa tese é seguida também por Watrous, a qual afirma que Praisos fundou o santuário em Palaikastro, na costa, para servir como o limite oriental de seu território (em face de Itanos a norte; Watrous, 1996, pp. 104-105).

Posições contrárias a essa tese foram propostas por Prent e Chaniotis. De acordo com Prent, é difícil afirmar se Praisos teria tido parte na fundação do santuário na Idade do Ferro, "diante das evidências de similaridades entre o santuário de Palaikastro e aquele do "Altar Hill" em Praisos, tal como defendeu Bosanquet" (Prent, 2005, p. 537). A seu ver, "a participação de Praisos no controle do santuário pode ser atestada para períodos mais posteriores, como indica a similaridade entre as antefixas de górgona, datados entre os séculos VI-V a.C., encontrados em Palaikastro e muito semelhantes aos do santuário em Praisos" (Prent, 2005, p. 538). Prent, como Chaniotis, não relaciona a fundação do santuário de Zeus a nenhuma comunidade emergente da região. Segundo Chaniotis, é 
Mare Nostrum, ano 2020, v. 11, n. 2.

provável que desde a Idade do Ferro o santuário de Zeus Dicteu não pertencesse a nenhuma comunidade em particular - a área sagrada estava em sua própria terra sagrada, era um santuário extra-territorial (Chaniotis, 2009, p. 64). Tal proposição, como veremos, se baseia em um testemunho muito posterior, na interpretação da inscrição de Toplou, datada do século II a.C.

A tese de Chaniotis sobre o caráter extra-territorial do santuário de Palaikastro é complementar àquela de Prent que, a nosso ver, parece ser a mais acertada sobre a fundação do santuário, já que se baseia somente nas evidências arqueológicas da Idade do Ferro e não apenas em testemunhos literários e arqueológicos posteriores. Segundo a tese de Prent, "razões territoriais e outras considerações práticas, como o acesso a um bom porto, parecem ter sido menos relevantes, do que em Amnisos, na escolha do local para o estabelecimento da área sagrada, já que não há importados entre o conjunto de objetos votivos do santuário de Palaikastro, que indicariam contatos além-mar" (Prent, 2005, p. 538). Também não encontra justificativa na documentação "atribuir ao santuário a função de marcar fronteiras agrícolas de uma das comunidades do leste de Creta, pois há escassez de pequenos assentamentos de agricultores no período nas áreas costeiras" (Prent, 2005, pp. 538-539). Para Prent, "parte da razão da localização do santuário nas ruínas da cidade minoica se deve, em primeiro lugar, à natureza remota da área no período - no aspecto significativo da área, na memória respeitável da grandeza de outrora da antiga cidade - e à associação da área de Palaikastro com o culto de um importante deus local" (Prent, 2005, pp. 539-540). Em segundo lugar, foi a localização em uma área dedicada originalmente ao pastoreio ${ }^{8}$ que estabeleceu a função do santuário como um local neutro de encontro (Prent, 2005, p. 539).

Esse mesmo autor é também o único que sugere um papel do santuário de Zeus Dicteu na formação de uma identidade local, típica do leste de Creta. Conforme Prent, "mais do que atrair visitantes de além-mar, e servir na manutenção de contatos entre indivíduos de outras regiões, como a gruta de Ida também dedicada ao culto de Zeus, por exemplo, o santuário de Palaikastro ajudou a criar e a reforçar, por meio de uma antiga divindade regional, uma identidade típica comum no lado leste de Creta" (Prent, 2005, p. 545). Esse autor assume que "essa identidade regional tomou a forma de uma consciência autóctone ou eteo-cretense a partir da Idade do Ferro e em diante” (Prent, 2005, p. 545). Esse papel, segundo Prent, teria sido motivado pela localização de Palaikastro em uma

\footnotetext{
${ }^{8}$ Para Chaniotis, essa é uma função comprovada apenas nos santuários extra-urbanos do Mt. Ida e de Syme (Chaniotis, 2009, p. 64).
} 
região de Creta amplamente desabitada e isolada, diferente, por exemplo, do caso da gruta de Ida, situada na confluência de três diferentes regiões no lado central da ilha, fator que teria levado esse santuário a atrair comunidades de várias regiões cretenses (Prent, 2005, p. 545).

O padrão do culto de Zeus Dicteu, descrito até o momento, em época arcaica manteve-se quase inalterado, conforme indicam a continuidade dos tipos de objetos votivos e a narrativa presente no relevo das simae do templo arcaico, de acordo com a interpretação de Driessen-Gaignerot. Certa transformação deve ter ocorrido em época arcaica, quando o culto foi abrigado, pela primeira vez, em um templo. Já em época clássica, os autores supõem o declínio de sua característica original aristocrática e militar, conforme indica o fim da dedicação de escudos e o predomínio de cerâmicas e lamparinas (Kreutz, 2007, p. 134; Prent, 2005, p. 550). Segundo Kreutz, “em época clássica houve uma perda de importância do santuário, retomada somente durante o período helenístico, quando Palaikastro certamente se converteu em um lugar de ritos noturnos, como indicam os inúmeros fragmentos de lamparinas" (Kreutz, 2007, p. 134). A seu ver, "embora não tenham sido consagrados mais escudos após o período arcaico, o hino a Zeus Dicteu mostra que a memória da dança dos Kouretes sobreviveu" em época helenística e posteriormente (Kreutz, 2007, p. 134). E Chaniotis defende o rito dos efebos no santuário de Palaikastro, em época helenística, com base sobretudo no hino dos Kouretes, cujo texto é atribuído também ao período entre os séculos VI-III a.C. (Chaniotis, 2009, pp. 64-65).

Da época helenística datam as primeiras informações sobre a participação das comunidades locais e seu interesse pelo santuário em Palaikastro. A esse respeito, a inscrição de Toplou (I.Cret. III.iv, 9ab), do século II a.C., descreve uma longa disputa territorial entre várias cidades do leste de Creta em relação ao santuário de Zeus Dicteu no período (Prent, 2005, p. 534). Há duas interpretações diferentes sobre o texto da inscrição. Para a maioria dos estudiosos, o texto se refere a uma disputa entre Hierapytna e Itanos pelo controle do santuário em Palaikastro. Nessa perspectiva, Hierapytna, no texto, clama pela possessão do santuário após destruir Praisos que, segundo o texto de Estrabão, era a cidade que controlava a área sagrada até antes de ser destruída (Pearlman, 1995, p. 165; Prent, 2005, pp. 534-535). Itanos, por sua vez, reivindicava o santuário, afirmando que este estava dentro de suas terras a sul, herdadas de seus ancestrais (Perlman, 1995, p. 165). De acordo com a interpretação mais recente, proposta por A. Chaniotis e baseada na contextualização dos termos gregos, o objeto de disputa, na realidade, não era o controle do santuário ou de sua área, mas a terra vizinha - Itanos 
Mare Nostrum, ano 2020, v. 11, n. 2.

afirmava que a terra era deles, já Hierapytna que esta era sagrada a Zeus, pertencia à divindade (Chaniotis, 2009, p. 63). Para esse estudioso, a terra era sagrada a Zeus e não poderia pertencer ao território cívico nem de Itanos e nem de Hierapytna (Chaniotis, 2009, p. 63). É por essa razão que Chaniotis conclui que o santuário de Zeus Dicteu em Palaikastro era extra-territorial - não pertencia ao território de nenhuma cidade em particular (Chaniotis, 2009, p. 64). Outro testemunho do envolvimento de comunidades políticas no santuário em Palaikastro, também nesse período, é uma inscrição referente a um tratado entre Hierapytna e Cnossos, encontrado no santuário (I.Cret. Iviii, 13; Chaniotis, 2009, p. 64). Uma das cláusulas do tratado impunha a colocação de uma estela, de ambas as partes, no santuário de Zeus Dicteu (Chaniotis, 2009, p. 64). Essa inscrição é considerada uma evidência de que, em época helenística, o santuário de Zeus Dicteu, em Palaikastro, atraiu comunidades para além de sua localização no lado extremo leste, como indica a participação de Cnossos, localizada no lado centro-norte de Creta (Kreutz, 2007, p. 135).

Embora inscrições indiquem que o santuário continuou a funcionar como um importante lugar de culto para os habitantes das cidades a leste de Creta nos períodos helenístico e romano, de acordo com Chaniotis, "os rituais efébicos no santuário em Palaikastro foram interrompidos com a chegada dos romanos, e a interrupção desses rituais significou o fim da função da área sagrada como um local de culto supra-local" (Chaniotis, 2009, p. 65; MacGillivray \& Sackett, 2010, p.575).

Esse é o estado atual das pesquisas a respeito do santuário de Zeus Dicteu em Palaikastro. Sobre a origem do culto e a fundação do santuário, concordamos com M. Prent e A. Chaniotis. A associação antiga da área a Zeus Dicteu, a qual remonta à época minoica, muito provavelmente levou à fundação do santuário ao deus em meio às ruínas da antiga cidade durante a Idade do Ferro. A nosso ver, o santuário, que já não pertencia ao território de nenhuma comunidade emergente, pode ter sido fundado pela população de várias comunidades da área, como pela população de um assentamento específico que, pelo caráter antigo e regional da divindade, não limitou o culto à sua própria comunidade.

Nessa perspectiva, o santuário em Palaikastro, de fato, nunca teria sido ou se transformado em um centro de culto cívico. Se o local de culto não pertenceu a nenhuma comunidade específica do lado leste de Creta, acreditamos ter sido provável a participação de Praisos, em algum nível, no santuário desde os períodos mais antigos. Ora, dentre as três póleis que se relacionaram à área sagrada em época helenística (Praisos, Hierapytna e Itanos), Praisos era a mais antiga, a única, no extremo leste de Creta, que alcançou 
desenvolvimento urbano já na Idade do Ferro - a ocupação do assentamento data do minoico tardio IIIC até o século II a.C. (Pearlman, 2004, p. 1184). De acordo com P. Pearlman, Hierapytna foi fundada somente no final do século V a.C., enquanto Itanos já devia existir como pólis em época arcaica, conforme indicam principalmente inscrições desse período (Pearlman, 2004, pp. 1166-1167). Durante a Idade do Ferro, Praisos era a comunidade mais organizada na área e, por isso, pode ter tido certa primazia na participação do culto, talvez como administradora do santuário tal como é possível ver na comparação entre os remanescentes dos santuários de Zeus Dicteu em Praisos e em Palaikastro nesse período. Essa primazia deve ter continuado em época arcaica e clássica, como indicou M. Prent com relação às antefixas encontradas. Assim, mesmo diante da falta de testemunhos sobre quais comunidades frequentaram o santuário na Idade do Ferro ou em época arcaica e clássica, é possível considerar que, a partir do período arcaico, Itanos se envolveu no culto enquanto comunidade política estabelecida, assim como Hierapytna a partir do século V a.C. Mas, se é difícil estabelecer a participação das póleis do leste de Creta no culto, é impossível saber, no estado atual das pesquisas, se centros cretenses de outras áreas da ilha também procuraram o santuário em ambos os períodos.

Além de provavelmente ter controlado o santuário de Zeus Dicteu em Palaikastro, veremos, na sequência, que Praisos teve um santuário também atribuído à divindade.

\section{O santuário de Zeus Dicteu em Praisos}

Localizado a sudoeste de Palaikastro, também no extremo leste de Creta, em Praisos, o santuário atribuído a Zeus Dicteu foi estabelecido no topo da terceira acrópole, na denominada "colina do altar" $(325 \mathrm{~m})$, que se situa na rota de acesso sul à cidade e a sudoeste das demais colinas do assentamento (Figura 9; Prent, 2005, p. 304). Os remanescentes do santuário foram descobertos por Halbherr, cujas escavações em 1894 "revelaram um provável altar no meio do topo da colina" (Prent, 2005, p. 304). Restos sacrificiais foram estudados por Bosanquet em 1901 (Prent, 2005, p. 304). 


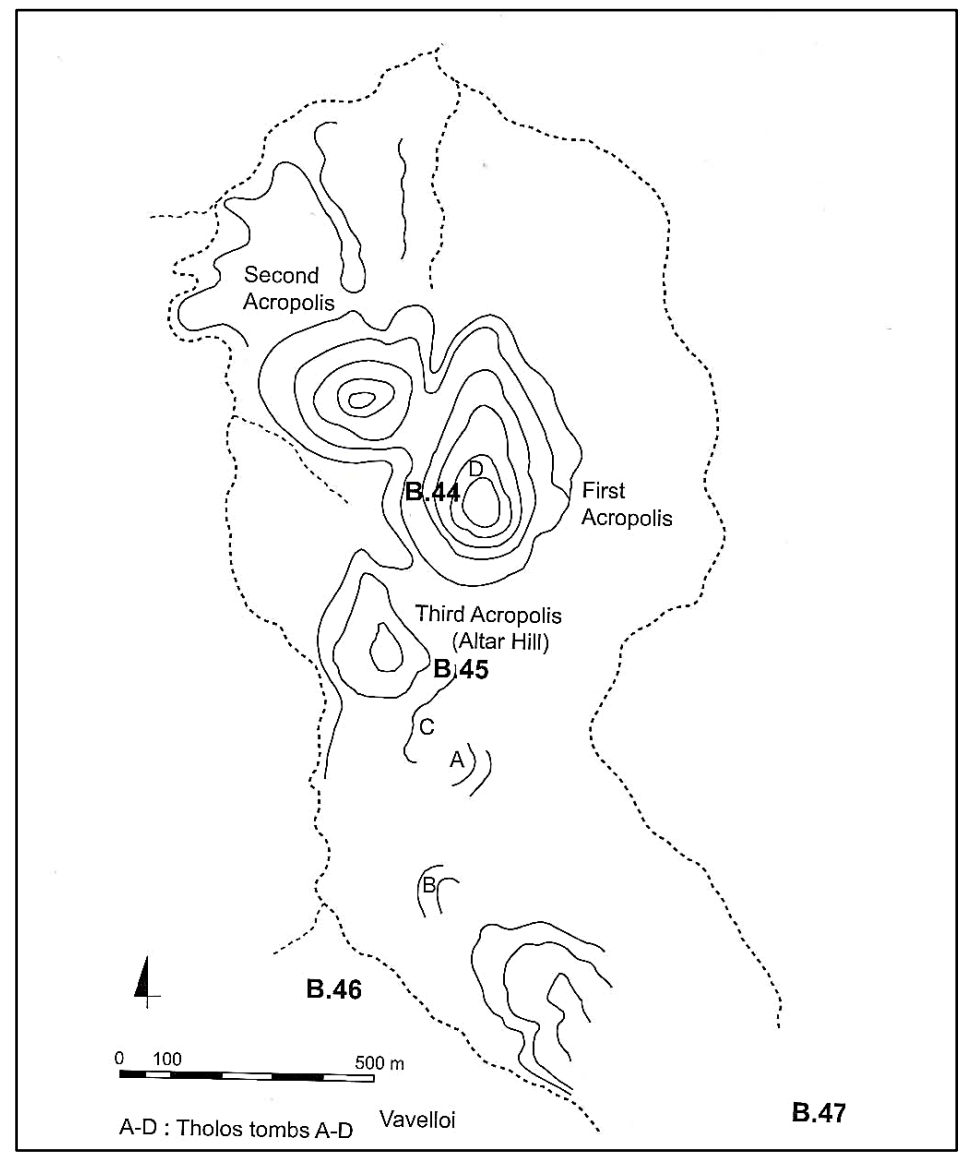

Figura 9. Planimetria de Praisos, B. 45. Identifica a área do santuário de Zeus Dicteu. Fonte: Prent, 2005, Figura 52.

\subsection{Os achados arqueológicos}

Os objetos votivos, os restos sacrificiais e partes da estrutura do altar são os únicos remanescentes disponíveis para a reconstituição da história do santuário. Do altar, a escavação de Halbherr encontrou "dois muros baixos de 4,95m e 5,95m de comprimento, feitos de em uma única fileira de pedras e construídos defronte ao afloramento de calcário, cercando uma área na qual o escavador encontrou traços de queima, ossos de bois e carneiros queimados e votivos de terracota e bronze" (Prent, 2005, p. 304). Em seu estudo dos achados, "Bosanquet concluiu que atividades posteriores de construção misturaram o nivelamento e distribuição do estrato datado entre a época geométrica e Orientalizante" - informações sobre a estratigrafia e a posição dos objetos é ausente nos relatórios de escavação mais antigos (Prent, 2005, p. 304).

Sobre os objetos votivos, estes foram encontrados misturados a fragmentos de ossos de animais e são datados entre os séculos VIII e V a.C. - o geométrico tardio é 
considerado, portanto, o período de início da atividade cultual na área sagrada (Prent, 2005, p. 304). As dedicações em bronze incluem trípodes ou caldeirões, pequenos discos, seis miniaturas de elmos e um elmo coríntio grande (Figura 10), uma lança, pontas de lança, uma fíbula, fragmentos de corpetes, caneleiras, uma cabeça de machado, fragmentos de ao menos duas estátuas menores do que o Kouros de Dreros e apenas a figurinha de um carneiro foi registrada (Prent, 2005, pp. 304-305; Zolotnikova, 2013, p. 114). Já imitações de escudos, da Idade do Ferro, figurinhas, a maior parte datada do século VI a.C., figuras cilíndricas femininas e figurinhas de touro, ambos os tipos datados da Idade do Ferro, compõem o conjunto de dedicações em terracota encontradas na área sagrada (Prent, 2005, p. 305). Segundo Prent, “embora nos relatórios seja dito que foi encontrado um número significativo de cerâmicas, apenas dois pequenos kalathoi, fragmentos de um jarro do geométrico tardio, duas ânforas, e fragmentos de pithos aparecem descritos ou ilustrados" (Prent, 2005, p. 305).

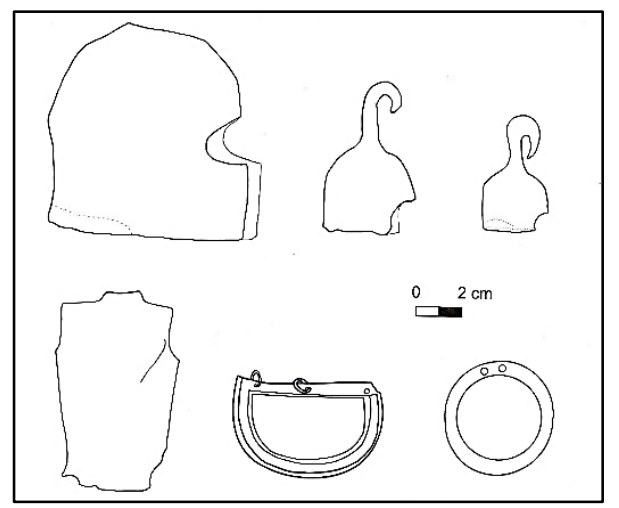

Figura 10. Objetos votivos de bronze relativos às armaduras Fonte: Prent, 2005, Figura 53.

Embora a bibliografia não informe sobre achados de época clássica e helenística, assume-se que o santuário funcionou até a destruição da cidade em época helenística, com base no testemunho de Estrabão a respeito do templo.

\subsection{O tipo de culto e a função do santuário}

O santuário sobre a terceira acrópole de Praisos tem sido identificado como um lugar de culto a Zeus com o epíteto Dicteu a partir de uma referência literária em Estrabão e dos tipos de objetos votivos, principalmente das semelhanças entre estes encontrados na área sagrada na denominada colina do altar e aqueles recuperados em Palaikastro. 
Mare Nostrum, ano 2020, v. 11, n. 2.

Estrabão (Geogr., 10.4.6) propicia um testemunho que indica a existência de um templo dedicado a Zeus Dicteu, mas sem fornecer qualquer informação adicional sobre sua localização, por exemplo. Já que os achados da área sagrada sobre a colina do altar indicam terem pertencido ao santuário "mais importante de Praisos"9 , os especialistas têm considerado se tratar do santuário do templo noticiado pelo geógrafo grego, apesar de nenhum remanescente do edifício ter sido encontrado na área. Uma referência no mapa de Bonsaquet de uma estrutura helênica, na encosta norte da terceira acrópole, é a única estrutura que poderia ser relacionada ao templo, mas infelizmente não há uma descrição e discussão do estudioso sobre tal construção (Prent, 2005, p. 306).

Foi Bosanquet que "primeiro atribuiu o santuário na colina do altar a Zeus Dicteu baseando-se nos votivos de armas e em particular nos discos pequenos de bronze, interpretados como címbalos usados no ritual de êxtase na dança dos Kouretes, já as terracotas de leão (de uma data tardia), a seu ver, talvez indiquem que Rhea foi cultuada ao lado do filho" (Prent, 2005, p. 306). Além disso, o estudioso percebeu similaridades na prática de culto e nos tipos de votivos entre os santuários de Palaikastro e o de Praisos - em ambos os locais o culto ocorria a céu aberto e era centrado em um altar de cinzas e as oferendas predominantes eram grandes quantidades de trípodes e miniaturas de armas em bronze (Prent, 2005, p. 535).

Como vimos, na opinião de M. Prent, as similaridades entre a prática de culto e os objetos votivos da Idade do Ferro de ambos os santuários são consideráveis, mas não provas suficientes para atestar a relação entre ambos, tal como postula Bosanquet (Prent, 2005, p. 537). Não descartando a interferência de Praisos sobre Palaikastro ao longo do tempo, segundo esse autor, os séculos VI-V a.C. é o único período em que de fato essa pólis pode ter interferido no santuário em Palaikastro e sido responsável por um programa de construção, como indicam o templo arcaico e a similaridade entre as antefixas encontradas nos dois sítios, mencionadas anteriormente.

Assim, também no caso de Praisos o santuário, que remonta à Idade do Ferro, foi atribuído ao culto de Zeus com base em fontes literárias tardias, não havendo sequer qualquer analogia com um culto minoico local tal como há para os santuários de Zeus no Mt. Ida, no Mt. Dicta, em Agia Triada, Amnisos e Palaikastro. Como bem coloca Zolotnikova, "a identidade real da divindade cultuada na área, durante o início do período histórico, não é documentada e sua identificação atual com Zeus não pode ser atestada

\footnotetext{
${ }^{9}$ Como define Prent, 2005, p. 305.
} 
com certeza" (Zolotnikova, 2013, p. 114). A identificação do culto a Zeus Dicteu no santuário em Praisos pode ser considerada mais vaga em relação àquela das áreas sagradas do Mt. Ida, de Agia Triada, Amnisos e Palaikastro, onde o culto foi atribuído ao deus a partir de evidências epigráficas encontradas no local do assentamento ou no próprio santuário. O caso de Praisos é diferente dos demais santuários cretenses de Zeus, pois se trata apenas de uma menção literária ${ }^{10}$ a um templo, sem referenciais no tempo e no espaço em relação à cidade. Mas mesmo assim acreditamos ser possível relacionar o santuário no topo da colina do altar a Zeus Dicteu a partir da tradição local do extremo leste de Creta relativa ao culto da divindade, já bem estabelecida na Idade do Ferro, e também das semelhanças do aparato cultual e votivos com a área sagrada da divindade em Palaikastro, mesmo que a relação entre os dois sítios possa ser atestada apenas em época arcaica e clássica.

Com relação à função da área sagrada, "Bosanquet sugeriu que esta serviu como um santuário para a comunidade de pastores que viviam em vilarejos espalhados nas montanhas ao redor" (Prent, 2005, p. 306). Mas tal proposição não encontra relação com os tipos de objetos votivos dedicados na colina do altar - não foram encontradas figurinhas de terracota de animais ou mesmo em bronze que indiquem um culto pastoril ou agrário no local. Como bem definiu Prent, o culto no santuário em Praisos é caracterizado, predominantemente, "pela dedicação de grandes objetos em bronze e sacrifício de animais, que revela o papel dominante e estabelecido de homens de uma aristocracia" (Prent, 2005, p. 497).

De todos os santuários cretenses de Zeus ${ }^{11}$, a área sagrada de Zeus Dicteu em Praisos é a única estabelecida dentro de um assentamento que se desenvolveu em uma pólis a partir da Idade do Ferro. Trata-se, com muita probabilidade, do único santuário suburbano da divindade na ilha de Creta em um grande arco temporal, entre a Idade do Bronze e a época clássica (até meados do século IV a.C.). Há evidências de ocupação contínua em Praisos entre o período minoico tardio IIIC e o século II a.C., quando foi destruída (Pearlman, 2004, p. 1184). O assentamento começou sobre a primeira e a segunda acrópoles, como indicam os achados do período mais antigo da cidade (Pearlman, 2004, p. 1184). A maior parte dos achados da Idade do Ferro provém dos santuários relacionados à terceira acrópole, localizados fora da cidade (de Zeus Dicteu e

\footnotetext{
${ }^{10}$ Não há evidências epigráficas a respeito do santuário e do culto de Zeus Dicteu em Praisos.

${ }^{11}$ Para um estudo arqueológico completo dos santuários de Zeus em Creta e no mundo grego, ver Laky, 2016.
} 
Mare Nostrum, ano 2020, v. 11, n. 2.

Vavelloi) e à necrópole, situada na encosta sudeste dessa mesma colina (Pearlman, 2004, p. 1184). Não há informações sobre um circuito de muros de qualquer época nessa cidade.

Nessa perspectiva, o santuário de Zeus Dicteu em Praisos é o único também que pode ser relacionado, em algum grau, a outro local de culto dentro do mesmo assentamento, já que todos os outros santuários da divindade eram extra-urbanos e sem relação com algum centro. Nesse caso, trata-se do santuário, também suburbano, de Vavelloi, localizado na encosta de uma colina a c.900 m do assentamento, na rota sul de acesso a Praisos, como o santuário de Zeus (Prent, 2005, p. 497). Diferente do santuário localizado na colina do altar, o de Vavelloi é caracterizado por uma profusão de figurinhas em terracota (femininas e masculinas), datadas a partir do século VII a.C., e também plaquetas com imagens de jovens homens vestindo um longo quíton (Prent, 2005, p. 496).

Esses tipos de oferendas levaram os pesquisadores a concluir que se tratava de um santuário relacionado a rituais de transição à fase adulta e ao casamento (Prent, 2005, p. 496). Não foram encontradas, nesse santuário, terracotas mostrando guerreiros e nem votivos com fortes conotações militares, como ocorre no santuário de Zeus Dicteu (Prent, 2005, p. 497). Conforme explica Prent, o santuário de Vavelloi pertence a um tipo de santuário suburbano que promovia a coesão entre diferentes grupos sociais de uma mesma comunidade, em contraste com o tipo de área sagrada suburbana na colina do altar, onde o culto era restrito a um único grupo social da comunidade - uma elite de homens (Prent, 2005, p. 502). Esse autor parece sugerir que um festival complementar, ao culto em Vavelloi, pode ter ocorrido naquele de Zeus Dicteu, espaço de iniciação de jovens homens aristocratas (Prent, 2005, p. 497). Essa seria a única relação que se poderia estabelecer entre esses dois santuários de Praisos, com funções distintas e ao mesmo tempo complementares dentro da comunidade.

Uma última peculiaridade do santuário de Zeus Dicteu, em Praisos, é este estar situado dentro de um assentamento, cuja população se identificava como descendente dos eteo-cretenses $^{12}$ (Pearlman, 2004, p. 1183; Prent, 2005, pp. 546-547). São fontes literárias do período clássico e helenístico, como Heródoto (Historiae, 7.167-172) e Estrabão (Geogr.,10.4.6,12), que descrevem "os eteo-cretenses como uma população autóctone, etnicamente distinta, que vivia no leste de Creta, sendo especialmente relacionada, por esses autores, a Praisos (Prent, 2005, p. 535; p. 546). Inscrições em eteo-cretense, descobertas na terceira acrópole ou colina do altar, datadas a partir de época arcaica, são

${ }^{12} \mathrm{O}$ grupo é mencionado pela primeira vez em Homero (Prent, 2005, p. 548). 
provas de que esta era uma língua viva no período (Prent, 2005, p. 548). Segundo Prent, "não há provas de que o uso da língua no período arcaico serviu como um 'marcador étnico', naquela época, para distinguir a população autóctone do leste de Creta da população de fala grega nas outras partes da ilha" (Prent, 2005, p. 548). É provável que a língua tenha derivado, em algum grau, do minoico, sendo, portanto, ao lado de tradições religiosas, um dos elementos que teriam sido preservados da Idade do Bronze (Prent, 2005, pp. 548-549). Conforme o estudioso, "tais tradições eram revividas ou retomadas de tempo em tempo, podendo servir como âncoras para a elaboração de uma noção de identidade eteo-cretense" (Prent, 2005). Nessa perspectiva, na Idade do Ferro, “conotações eteo-cretenses podem ter servido a grupos da elite para se auto distinguir por meio de uma associação com o passado baseado na Idade do Bronze" (Prent, 2005, p. 550). Na época clássica e helenística, como deixam claro os testemunhos literários, essa identidade deve ter novamente emergido, sobretudo em época helenística, "nos conflitos políticos e militares no leste da ilha" (Prent, 2005, p. 549).

Em síntese, é nesse contexto que devemos compreender o culto de Zeus Dicteu em seu santuário em Praisos - "uma comunidade que se imaginava diferente de outras cretenses" - e mais amplamente no lado leste de Creta, como em Palaikastro (Prent, 2005, p. 547). Se no caso de Praisos não é possível determinar o papel do culto em termos regionais, mas apenas locais (com relação a uma mesma comunidade), deve-se ao menos considerar que o culto da divindade foi realizado por um grupo específico dentro da ilha de Creta. As inscrições em eteo-cretense, de época arcaica, são contemporâneas a uma fase importante do culto de Zeus Dicteu na terceira acrópole, indicando que, na época do funcionamento da área sagrada, a população se caracterizava como tal.

\section{Considerações finais}

Neste artigo, os santuários de Palaikastro e de Praisos foram descritos e discutidos a partir de sua respectiva área geográfica ou sub-região, em relação ao início da atividade cultual, à categoria de santuário, à documentação arqueológica, textual e/ou epigráfica disponíveis e, em última análise, em relação às diferentes fases dos santuários e do culto (como a pólis e os tipos de identidade foram articulados pelo culto ao longo do tempo). Como bem sintetizou L. Thromas com relação à Atena, que nos inspirou em nossa análise sobre Zeus Dicteu: devemos mostrar quais foram "as competências e atribuições da divindade no espaço" e "como se ligaram a ela a estrutura política e social das cidades 
Mare Nostrum, ano 2020, v. 11, n. 2.

onde houve o culto" e, especialmente no caso de Zeus, considerar também aquelas cidades que frequentaram seus santuários regionais (Thromas, 2009, pp. 63-64). Consideramos os santuários como "marcadores sociais que proporcionaram a definição e construção da identidade dos membros de uma dada comunidade" (Thromas, 2009, p. 66). Na interpretação de Palaikastro, sobre santuários extra-territoriais com funções regionais, seguimos a abordagem de A. Chaniotis, que vê esses tipos de áreas sagradas como locais onde uma identidade regional foi formada pelo encontro e interação com o outro (diferentes comunidades de igual ou diferente origem étnica) por meio da competição, do conflito e da diferenciação (Chaniotis, 2009, p. 61). Na definição do ritual relacionado ao culto das áreas sagradas do deus, consideramos também a definição de Chaniotis na qual rituais determinam e expressam relações hierárquicas, refletem tensões ou criam solidariedade e unidade na organização interna de uma comunidade e/ou com outras comunidades participantes também no santuário (Chaniotis, 2009, p. 65). Assim, a partir da premissa de que uma parte substancial dos rituais serviram para forjar a necessária coesão social entre os diferentes membros de uma comunidade, tentou-se compreender em que medida os santuários de Zeus foram restritos a determinados grupos políticos ou serviram à comunidade política como um todo.

Os santuários cretenses de Zeus em Palaikastro e Praisos não só articularam a identidade de um grupo, a aristocracia, mas tiveram um papel em articular identidades locais em uma ilha marcada pela diversidade entre as regiões. Esse foi o caso do culto de Zeus Dicteu no leste de Creta em seus dois santuários, principalmente em Palaikastro lá ajudou a criar e a reforçar, por meio de uma antiga divindade regional, uma identidade típica comum no lado leste de Creta" (Prent, 2005, p. 545).

Recebido: $21 / 08 / 2020$

Aprovado: $14 / 09 / 2020$ 
Lilian Laky. A Arqueologia de dois Santuários Cretenses de Zeus Dicteu.

\section{REFERÊNCIAS BIBLIOGRÁFICAS}

\section{Fontes}

Apolodoro (1976). Gods and heroes of the Greeks: the library of Appolodorus (Trad. Michael Simpson e Leonard Baskin). Amherst: University of Massachusetts Press.

Diodoro Sículo (1963). Library (Trad. C.H. Oldfather). Cambridge: Harvard University Press (The Loeb Classical Library).

Estrabão (1960). The Geography (Trad. Horace Leonard Jones). Cambridge, Mass; Londres: Harvard University Press (The Loeb Classical Library).

Heródoto (1960). The Histories. Books 5-7 (Trad. de A. D. Godley). Londres: William Heinemann; Cambridge Harvard University Press (Loeb Classical Library).

Glossário do LABECA. Endereço para acesso: <http://labeca.mae.usp.br/pt-br/glossary/> (Consultado em 24/10/2020 às 11h48min).

\section{Obras}

Chaniotis, A. (2009). Extra-urban Sanctuaries in Classical and Hellenistic Crete. In G. Deligiannakis \& Y. Galanakis (Eds.), The Aegean and its Cultures. Proceedings of the first Oxford-Athens graduate student workshop organized by the Greek Society and the University of Oxford Taylor Institution, 22-23 April 2005 (pp. 59-67). Oxford: Archaeopress.

Crowther, C. \& Macgillivray, J. A. (2003). 'The Hymn to Diktaian Zeus.' In J. M. Driessen, J. A. Macgillivray \& L. H. Sackett (Eds.), Ancient Palaikastro 1902-2002 (pp. 145-148). Atenas: The British School at Athens.

Driessen-Gaignerot, F. (2011). The frieze from the temple of Dictaean Zeus at

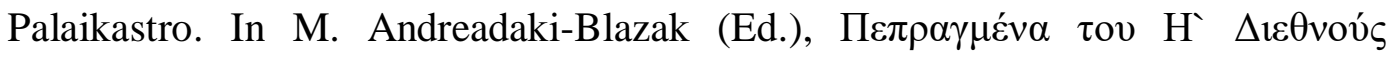

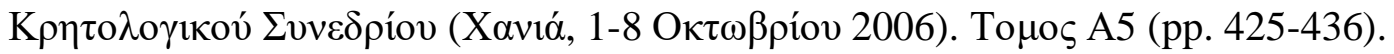
Chaniá: s/e.

Kreutz, N. (2007). Zeus und die griechischen Poleis: topographische und religionsgeschichtliche. Untersuchungen von archaischer bis in hellenistische Zeit. Rahden/ Westf.: Marie Leidorf (Tübinger archäologische Forschungen, 3). 
Mare Nostrum, ano 2020, v. 11, n. 2.

Laky, L. A. (2016). A apropriação e consolidação do culto de Zeus pela cidade grega, moedas e santuários, política e identidade em época arcaica e clássica. Tese de Doutorado - Universidade de São Paulo; Museu de Arqueologia e Etnologia.

Macgillivray, J. A. \& Sackett, L.H. (2000). The Palaikastro kouros: the Cretan god as a young man. In: J. A. Macgillivray, J. M. Drissen \& L. H. Sackett (Eds.), The Palaikastro kouros: a Minoan chryselenphantine statuette and its Aegean Bronze Age context (pp. 165-170). British School at Athens Studies 6. Londres.

Macgillivray, J. A. \& Sackett, L.H. (2010). Palaikastro. In E. H. Cline (Ed.), The Bronze Age Aegean (pp. 570-581). Oxford, Oxford University Press.

Pearlman, P. (1995). Invocatio and Imprecatio: The Hymn to the Greatest Kouros from Palaikastro and the oath in ancient Crete. JHS, 115, 161-167.

Pearlman, P. (2004). Crete. In H. H. Hansen \& T. Nielsen. An Inventory of Archaic and Classical Greek Poleis (pp. 1144-1195). Oxford: Oxford University Press.

Prent, M. (2005). Cretan Sanctuaries and Cults. Continuity and change from Late Minoan IIIC to the Archaic Period. Leiden, Boston: Brill.

Prent, M. \& Thorne, S. M. V. (2000). The sanctuary of Diktaean Zeus at Palaikastro: a

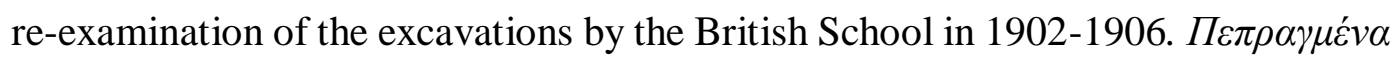

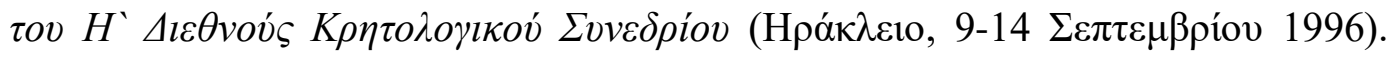
Heraklion, 169-178.

Sackett, L. H. (2002). The sanctuary of Dikataian Zeus. In J. M. Driessen, J. A. Macgillivray \& L. H. Sackett, Ancient Palaikastro: an exhibition to mark 100 years of archaeological work 1902-2002 (s./p). Atenas: The British School at Athens.

Thorne, S. e Prent, M. (2002). The sanctuary of Dikataian Zeus. In J. M. Driessen, J. A. Macgillivray \& L. H. Sackett, Ancient Palaikastro: an exhibition to mark 100 years of archaeological work 1902-2002 (s./p). Atenas: The British School at Athens.

Thromas, L. (2009). Espace politique et identité civique des cités péloponnésiennes aux époques archaïque et classique: les savoirs d'Athéna. Geographia Antiqua, 18, 6374.

Watrous, L. V. (1996). The Cave Sanctuary of Zeus at Psychro. A study of extra-urban sanctuaries in Minoan and Early Iron Age Crete. Liège: Université de Liège.

Willetts, R. F. (1962). Cretan Cults and Festivals. Londres: Routledge and Kegan Paul. 
Lilian Laky. A Arqueologia de dois Santuários Cretenses de Zeus Dicteu.

Zolotnikova, O. A. (2013). Zeus in the Early Greek Mythology and Religion: from prehistoric times to early archaic period. Oxford: Archaeopress. 
The Archaeology of Two Cretan Sanctuaries of Dictaean Zeus: The case of Palaikastro and Praisos from the Iron Age to the Hellenistic Period

\section{ABSTRACT}

From the cases of the Dictaean Zeus' sanctuaries in Palaikastro and Praisos, eastearn Crete, we present, in this article, the methodology of the archaeology of the Greek sanctuaries. Based on a thorough examination of the archaeological sources (mainly votive offerings) and literary sources, in association with the space of the sanctuaries in the landscape and in the territory of Greek cities, we will discuss the role of Dictaean Zeus' sanctuaries in the context of the polis formation on this side of Crete and in the articulation of the territories and the identity of the political communities of this region until the Hellenistic period. Ultimately, we aim to show how different data articulate and can reveal the social role of the Greek sanctuaries to specific communities.

\section{KEYWORDS}

Dictaean Zeus; Crete; sanctuaries; Palaikastro; Praisos. 